Vol. 5 (1996): 185-192.

\title{
Estimation of genetic parameters for test-day milk production at different stages of lactation of Finnish Ayrshire heifers
}

\author{
Anne Kettunen and Esa A. Mäntysaari \\ Agricultural Research Centre of Finland, Institute of Animal Production, FIN-31600 Jokioinen, Finland
}

\begin{abstract}
Genetic parameters for test-day milk production at different stages of lactation of Finnish Ayrshire heifers were estimated with the REML method using the AI algorithm and animal model. The data consisted of 38679 first lactation test-day milk yields of 4205 cows from 231 herds in three geographical regions (North Savo, Central Ostrobothnia and Lapland). To identify different test days, records were numbered according to the days in milk after calving, and were further categorized into three part-lactations according to the test-day classification. Expressions in the three part-lactations were considered as separate traits, and tests were treated as repeated observations within the trait. Heritability estimates for test-day milk yield varied between 0.11 and 0.17 , being lowest at the beginning of lactation. Genetic correlations between test-day milk yields at different trimesters ranged from 0.64 to 0.91 , being highest between consecutive trimesters. Standard errors of the estimates of genetic parameters varied between 0.02 and 0.08 . Genetic interrelationships differed from 1.0, supporting the assumption that genetic variation exists in the shape of the lactation curve. The necessity of considering deviations from the general lactation curve in the test-day model, e.g. fitting random regression coefficients, is discussed.
\end{abstract}

Key words: animal model, test-day model, lactation curve

\section{Introduction}

In Finland, as in many other countries, the estimation of breeding values for production traits of dairy cattle is based on 305-day lactation records of milk, protein and fat production, and on the protein and fat percentages in the corresponding milk. For milk-recorded herds, individual milk yields are measured every month at regular (approximately 30-day) intervals, and the concentrations of protein and fat in milk every other month. The lactation records are formed by combining the first ten monthly test-day yields, weighted by the length of the testing periods, into a measure of production.

In estimation of breeding values and in animal selection scheme it is advantageous to use the original test day measurements rather than the entire lactation production. There is then no need to combine individual test-day results into an entire lactation yield nor to extend incomplete 


\section{AGRICULTURAL AND FOOD SCIENCE IN FINLAND}

\section{Kettunen, A. \& Mäntysaari, E.: Genetic parameters for test-day milk}

lactation records. In the test-day model, the specific environmental conditions of the sample day can be accounted for by modelling the contemporary group to include all the animals sampled on a certain test day within the herd. This should result in smaller residual variance (Ptak and Schaeffer 1993). In the test-day model the amount of information is greater; instead of one measure of production per lactation, all information obtained during lactation can be used and the accuracy of evaluations may improve (Pander et al. 1992, Ptak and Schaeffer 1993). Furthermore, it is possible to weight test-day measurements according to their (co)variance structure (Ali and Schaeffer 1987).

When the animal evaluation is based on $305-$ day production, a common underlying lactation curve for all animals is assumed. In the test-day model, factors for modelling the curve of lactation can be included (Ptak and Schaeffer 1993), and different lactation curves can be delineated for different subgroups if necessary. The use of continuous evaluation and the test-day model rather than one-shot evaluation would make it possible to obtain updated evaluations of a particular herd immediately after each new test day. Solutions for herd-test day effects and individual animal deviations from the predicted production can be used in dairy management and to detect problems in herd feeding or health programmes.

In most studies the variance components of test-day measurement data have been estimated for either individual test days or for yields cumulated periodically (see review by Swalve 1995b). Heritability estimates for the mid-part of lactation are of the same order of magnitude as those estimated for 305-day production, and considerably lower for the beginning and end of lactation (Meyer et al. 1989, Pander et al. 1992, Swalve 1995a). Genetic correlations between consecutive test days are close to unity, decreasing when the distance between test days increases (Meyer et al. 1989, Pander et al. 1992, Kahtenbrink and Swalve 1993, Rekaya et al. 1995). Genetic relationships between test-day yields and the entire lactation production depend on the stage of lactation, being lowest during the first two test days and highest during the mid-part of lactation (Pander et al. 1992, Kahtenbrink and Swalve 1993).

One parameter of the lactation curve that is of economic importance to the dairy producer is persistency (Gravert and Baptist 1976). Generally persistency describes how sharply the lactation curve peaks, and how strong the decrease in daily production is after the peak. Cows maintaining consistently high production throughout lactation are considered persistent. First lactating cows are usually more persistent than cows in later parities (Danell 1982). At the same level of production, persistent cows are under much less physiological stress, and thus metabolic disorders or problems with health and fertility are less probable (Leukkunen 1985, Swalve 1995c). It is much easier to meet the feeding requirements of a persistent cow, and therefore it is possible to keep the proportion of roughage in the daily diet high (Danell 1982, Leukkunen 1985, Swalve 1995c). This has economic importance, especially in geographical areas where self-sufficiency in feedstuff production is based on hay and silage, and grain or concentrates being mainly bought elsewhere. Persistency correlates favourably with 305-day milk yield and the test-day milk production, except in early lactation (Danell 1982, Swalve 1995c).

The shape of the lactation curve can be estimated with various mathematical models, of which those widely used are Wood's gamma function (Wood 1967) and the multiple regression model (Ali and Schaeffer 1987). As there is evidence of genetic variation in persistency (Danell 1982), individual differences in the shape of the lactation curve may have to be considered. This can be done with a multitrait model in which each test-day yield is considered as a different trait. Another alternative is to use a single-trait model in which test-day yields are considered as repeated observations and individual deviations from the general lactation curve are accounted for by estimating lactation curve parameters within cows (Schaeffer and Dekkers 1994). The breeding value of an animal is then a 


\section{AGRICULTURAL AND FOOD SCIENCE IN FINLAND}

Vol. 5 (1996): 185-192.

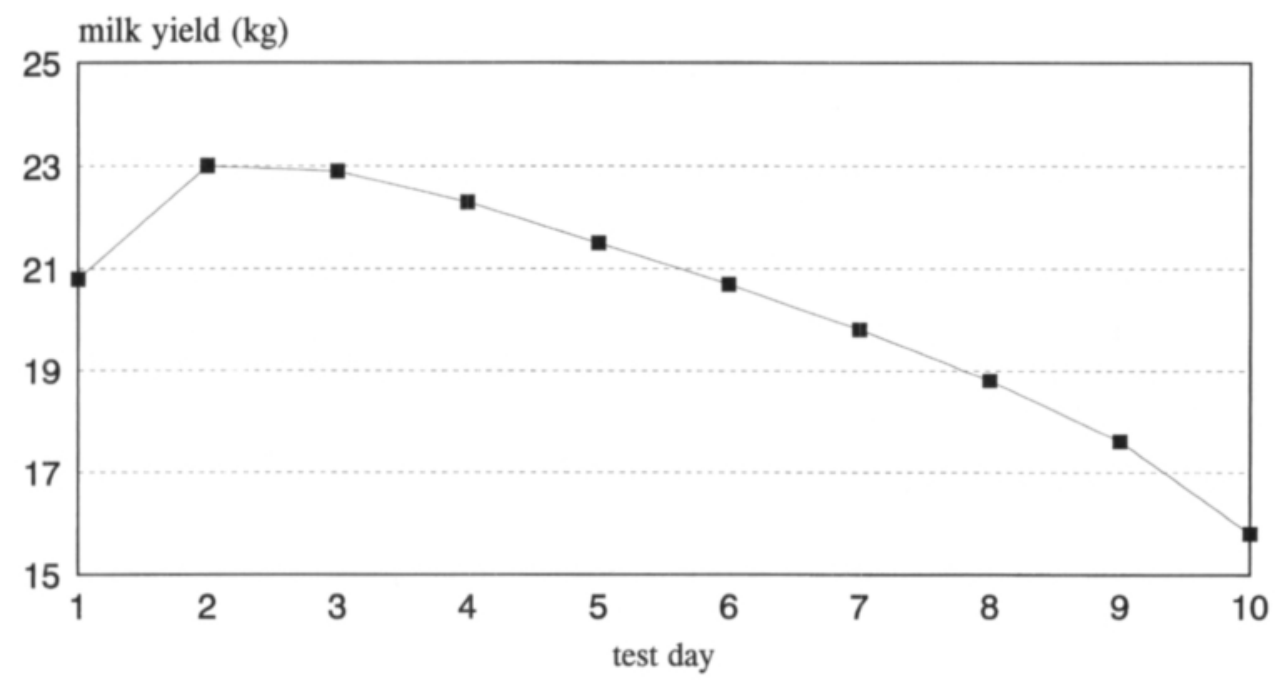

Fig.1. Lactation curve for milk yield from average phenotypic test-day milk production $(\mathrm{n}=38679)$.

combination of the genetic value determining the height of production and the genetic value of the shape of the lactation curve.

Here, heritabilities were estimated for testday milk yields at different stages of the lactation of Finnish Ayrshire heifers with a test-day model, and the genetic correlations between testday milk yields at different stages of lactation were determined. The need to include lactation persistency in the breeding value estimation is discussed in the light of the results.

\section{Material and methods}

Test day data were extracted from the national milk-recording database in three geographical regions (North Savo, Central Ostrobothnia and Lapland). For this study, the data were restricted to the first lactation records of Ayrshire cows calving between April 1991 and March 1995. As in the national milk recording system, cows producing less than $6.0 \mathrm{~kg}$ of milk on a test day were considered dry. To enable the computations to be made with a multitrait model, the data were further edited with respect to the number of an- imals in the contemporary comparison group, only the herds with more than three heifers calving in each herd-year class being included in the analyses. A total of 38679 test day milk production records for 4205 cows from 231 herds were used in the estimation of genetic parameters.

Test days (TD) were identified by numbering records according to the days in milk (DIM) after calving. Equal 30-day intervals were used to classify test days $1-9$; the test made during days 271 to 305 after calving was classified as test day 10. If a cow's two successive test-day samples fell in the same test-day class, only the last one was considered. For the estimation of genetic parameters, the test-day classes were further grouped into three part-lactations according to the stage of lactation. The first trimester consisted of the first two test days (1-60 DIM), the second trimester ranged from the third to sixth test day (61-180 DIM) and the last trimester from the seventh to tenth test day (181-305 DIM). No restriction was made according to the number of test day records during lactation. The average test-day milk production peaked during 31-90 days after calving and then declined quite linearly to the end of lactation (Fig. 1). The variances of the test-day milk yields were fairly 


\section{AGRICULTURAL AND FOOD SCIENCE IN FINLAND}

Kettunen, A. \& Mäntysaari, E.: Genetic parameters for test-day milk

Table 1. Number of observations $(\mathrm{N})$, means and standard deviations (SD) of test-day milk yield classified according to days in milk (DIM).

\begin{tabular}{|c|c|c|c|}
\hline Test day (DIM) & $\mathrm{N}$ & Mean & SD \\
\hline$(<31 \mathrm{~d})$ & 3744 & 20.8 & 4.3 \\
\hline 2. $(31-60 d)$ & 3994 & 23.0 & 4.4 \\
\hline 3. $(61-90 d)$ & 4017 & 22.9 & 4.4 \\
\hline 4. $(91-120 \mathrm{~d})$ & 3995 & 22.3 & 4.5 \\
\hline 5. $(121-150 \mathrm{~d})$ & 3977 & 21.5 & 4.5 \\
\hline 6. (151-180d) & 3970 & 20.7 & 4.4 \\
\hline 7. $(181-210 d)$ & 3931 & 19.8 & 4.4 \\
\hline 8. (211-240d) & 3892 & 18.8 & 4.3 \\
\hline 9. $(241-270 \mathrm{~d})$ & 3746 & 17.6 & 4.3 \\
\hline 10. $(271-305 d)$ & 3413 & 15.8 & 4.4 \\
\hline
\end{tabular}

homogeneous throughout lactation (sd. 4.3-4.5). Characteristics of the data are presented in Table 1 and Table 2.

Genetic parameters were estimated using a multitrait animal model in which expressions in each trimester were considered as repeated observations of a different trait. The statistical model used for describing the test-day milk yield for each trait was:

$$
\begin{aligned}
y_{i j k l m n o} & =H D_{i}+A G E_{j}+D C C_{k}+Y S_{l}+b * D I M_{i j k l m n o} \\
& +H Y_{m}+p e_{n}+a_{n}+e_{i j k l m n o}
\end{aligned}
$$

where:

$y_{i j k \text { mno }}=$ test-day yield (milk kg),

$H D_{i}=$ fixed effect of herd, $i=1-231$,

$A G E_{j}=$ fixed effect of calving age, $j=1-8$,

$D C C_{k}=$ fixed effect of days carried calf, for traits 2 and $3, k=1-5$,

$Y S_{l}=$ fixed effect of calving year-season, $l=1-23$,

$b=$ regression coefficient for test-day milk pro-

duction on days in milk (DIM),

$D I M_{i j k l m n o}=$ days in milk at test,

$H Y_{m}=$ random effect of herd-calving year,

$p e_{n}=$ random effect of permanent environment,

$a_{n}=$ additive genetic effect of animal,

$e_{i j k \text { lmno }}=$ random residual error pertaining to $y_{i j k l m n o^{\circ}}$

The effect of calving age was divided into eight classes according to the age of the heifer on the day of calving (Table 3). As the effect of pregnancy on milk yield cannot be found in the
Table 2. Number of observations $(\mathrm{N})$, means and standard deviations (SD) of test-day milk yield in trimesters grouped according to test day classification (TD).

\begin{tabular}{lrcc}
\hline Trimester & $\mathrm{N}$ & Mean & SD \\
\hline 1. (TD1-TD2) & 7738 & 21.9 & 4.5 \\
2. (TD3-TD6) & 15959 & 21.9 & 4.5 \\
3. (TD7-TD10) & 14982 & 18.1 & 4.6 \\
\hline
\end{tabular}

first trimester, its effect was considered only in later trimesters. The DCC effect was divided into five classes according to the duration of pregnancy on the sample day (Table 3). The calving year-seasons were classified into bimonthly periods within each calving year across herds, forming 23 calving year-season classes. From the lactation curve, estimated by phenotypic test-day means, production was observed to be approximately linearly dependent on the time from calving to sample day within each trimester (Fig. 1). Therefore DIM was included as a covariate in the model. Calving years, each from April to March and the years from 1991 to 1995 , were classified within herds to form 867 herd-calving year classes. The variances $\operatorname{Var}($ hy $)=\mathrm{I} \otimes \mathrm{HY}_{0}$, $\operatorname{Var}(\mathrm{pe})=\mathrm{I} \otimes \mathrm{PE}, \operatorname{Var}(\mathrm{a})=\mathrm{A} \otimes \mathrm{G}_{0}$ and $\operatorname{Var}(\mathrm{e})=\mathrm{I} \otimes \mathrm{R}_{0}$ were assumed where $I$ is an identity matrix and $\mathrm{A}$ is the additive relationship matrix of animal effects.

The matrices $\mathrm{HY}_{0}, \mathrm{PE}_{0}, \mathrm{G}_{0}$ and $\mathrm{R}_{0}$ are matrices of order 3 , describing the (co)variance structure of the traits. For computational reasons, pedigree information from the dam side was re-

Table 3. Classification of calving age (AGE) and days carried calf (DCC) effects.

\begin{tabular}{lrr}
\hline Class & AGE (days) & DCC (days) \\
\hline 1 & missing & $\leq 119$ \\
2 & $\leq 690$ & $120-149$ \\
3 & $691-720$ & $150-179$ \\
4 & $721-750$ & $180-209$ \\
5 & $751-780$ & $\geq 210$ \\
6 & $781-840$ & \\
7 & $841-900$ & \\
8 & $\geq 901$ & \\
\hline
\end{tabular}


Vol. 5 (1996): 185-192.

Table 4. Structure of pedigree information.

\begin{tabular}{lrrr}
\hline $\begin{array}{l}\text { Number of } \\
\text { progeny }\end{array}$ & \multicolumn{2}{c}{$\begin{array}{c}\text { Sires } \\
\mathrm{N}\end{array}$} & \multicolumn{1}{c}{$\begin{array}{c}\text { Dams } \\
\mathrm{N}\end{array}$} \\
\hline 1 & 153 & $(22 \%)$ & $2613(82 \%)$ \\
$2-5$ & 319 & $(47 \%)$ & $589(18 \%)$ \\
$6-10$ & 124 & $(18 \%)$ & \\
$11-20$ & 58 & $(9 \%)$ & \\
$>20$ & 27 & $(4 \%)$ & \\
\hline total & $681(100 \%)$ & $3202(100 \%)$ \\
\hline
\end{tabular}

stricted to include only female relatives whose first production year was 1982 or after. Cows with records were daughters of 681 sires and 3202 dams. On average sires had 6.2, and dams 1.3, daughters in the data. The total number of dam-daughter pairs with records in the dataset was 570 . The structure of the pedigree information is presented in Table 4.

Variance components were estimated with the restricted maximum likelihood (REML) method using the AI algorithm (average information). The average information matrix is taken as an average from Fisher's information matrix and the Newton-Raphson second derivative matrix (Johnson and Thompson 1995). Standard errors of the estimates of heritabilities and genetic correlations were estimated using the elements of the inverse of the average information matrix and a Taylor series expansion.

\section{Results and discussion}

Variance components and estimates of heritabilities and repeatabilities for test-day milk yields at different stages of lactation are presented in Table 5. Heritability estimates were $0.11,0.17$ and 0.17 for the first, second and third trimesters, respectively. Standard errors of the estimates of heritabilities were 0.02 for all three trimesters. Repeatability estimates within trimesters ranged from 0.52 to 0.71 (Table 5). Genetic correlations between trimesters were $0.88,0.64$
Table 5. Variance components for herd-year (HY), permanent environment (pe), animal effect and residual, and estimates of heritabilities and repeatabilities for test-day milk yield in lactation trimesters.

\begin{tabular}{lccc}
\hline $\begin{array}{l}\text { Variance } \\
\text { component }\end{array}$ & 1st trimester & 2nd trimester & 3rd trimester \\
\hline $\mathrm{HY}$ & 0.68 & 0.90 & 0.82 \\
pe & 5.27 & 6.84 & 6.32 \\
animal & 1.42 & 2.07 & 2.22 \\
residual & 6.11 & 3.62 & 4.42 \\
\hline $\mathrm{h}^{2}$ & $0.11 \pm 0.02$ & $0.17 \pm 0.02$ & $0.17 \pm 0.02$ \\
$\mathrm{r}$ & $0.52 \pm 0.01$ & $0.71 \pm 0.00$ & $0.66 \pm 0.01$ \\
\hline
\end{tabular}

and 0.91 between the first and second, the first and third and the second and third trimesters, respectively. Standard errors of the estimates of genetic correlations were low, ranging from 0.03 to 0.08 .

Additive genetic variance was lowest during the first trimester, increasing towards the end of lactation. Residual variance, in contrast, was considerably higher at the beginning of lactation than in the following two trimesters, indicating that the model did not describe early lactation as well as it did the rest of lactation (Table 5).

Heritabilities are typically estimated for individual test days (Meyer et al. 1989, Pander et al. 1992, Kahtenbrink and Swalve 1993, Reents et al. 1994, Rekaya et al. 1995, Swalve 1995a) or for cumulated or averaged yields in standardized intervals (Kahtenbrink and Swalve 1993, Swalve 1995a, b). Somewhat higher heritabilities for test-day milk production are presented in the literature than those found in three trimesters in this study. The definitions used in the records vary, however, and the statistical models and methods of estimation differ from those used here (see review by Swalve 1995b). Especially test-day milk production at mid-lactation is reported to be much more heritable than was found here (Pander et al. 1992, Kahtenbrink and Swalve 1993, Swalve 1995b). Comparison with estimates of heritabilities for 305-day milk production is invalid, because the trimesters are assumed to be different traits. However, with the 


\section{AGRICULTURAL AND FOOD SCIENCE IN FINLAND}

\section{Kettunen, A. \& Mäntysaari, E.: Genetic parameters for test-day milk}

Table 6. Variance components for herd-year (HY), permanent environment (pe), animal effect and residual, and estimates of heritabilities and repeatabilities for test-day milk yield in lactation trimesters when fixed herd effect was excluded from model.

\begin{tabular}{lccc}
\hline $\begin{array}{l}\text { Variance } \\
\text { component }\end{array}$ & 1st trimester & 2nd trimester & 3rd trimester \\
\hline $\mathrm{HY}$ & 3.93 & 5.52 & 4.66 \\
pe & 4.52 & 5.87 & 5.65 \\
animal & 2.35 & 3.32 & 3.07 \\
residual & 6.10 & 3.62 & 4.42 \\
\hline $\mathrm{h}^{2}$ & $0.18 \pm 0.03$ & $0.26 \pm 0.03$ & $0.23 \pm 0.03$ \\
$\mathrm{r}$ & $0.53 \pm 0.01$ & $0.72 \pm 0.00$ & $0.66 \pm 0.01$ \\
\hline
\end{tabular}

aid of heritabilities and repeatabilities it was possible to construct selection indices for cumulative yields over each period. The squared accuracy of such indices (comparable to $\mathrm{h}^{2}$ ) would then be $0.14,0.22$ and 0.23 for the first, second and third trimesters, respectively.

In the literature, higher heritabilities are estimated for the test-day records with herd-test day models than for the traditional herd-yearseason (HYS) classification (Swalve 1994, Rekaya et al. 1995). In our study the herd-test day classification could not be used because of the small size of the contemporary comparison group; the random herd-calving year (HY) was used as a contemporary comparison group instead. The fixed herd effect was included in the model to account for between-herd variation. Such an HY definition pools together the test months of a period of one year or more, and hence does not have the accuracy of even HYScalving groups in other studies.

Exclusion of the fixed effect of herd in the model affected heritability estimates (Table 6). When the herd effect was removed from the model, herd-year variation increased significantly. There was also some increase in the additive genetic variance, with a decrease in the component of permanent environmental variance. It was assumed that ignoring the fixed herd effect would make it impossible to fully differentiate between the part of the variation due to between-herd dif- ferences and the part due to the within-herd variation between calving years. Part of the between-herd variation seemed to enter the additive genetic component, and the effect of permanent environment became less detectable. No change in residual variance component was noted, thus leading to overestimation of heritabilities when the fixed herd effect was excluded from the model (Table 6). On the other hand, the structure of the data could have caused problems in distinguishing the effects of the factors in the model. Because the young sires in the AI-testing program (artificial insemination) are used for only limited periods, and possibly in only a few herds, the low heritability estimates may result from the fact that sires and herds and/or sires and calving year-season effects are confounded.

\section{Conclusions}

As a result of lower additive genetic variance and higher residual variance, the heritability estimate for test-day milk production in the first trimester of lactation was lower than that in the two following trimesters. The first test-day yield at the beginning of lactation, which is often sampled only a few days after calving, is presumably a less reliable measure of test-day milk production than later yields. Many environmental factors, such as feeding before calving, may significantly affect the cows' performance on the first test day. The variation caused by these nuisance factors might be very hard to account for, and at least was not distinguished by the model used here. This was indicated by the larger residual variance for the first trimester than for the other two trimesters.

Genetic correlations between the trimesters of the lactation were estimated to range from 0.64 to 0.91 , being highest between consecutive trimesters. The fact that the interrelationships between different parts of lactation were lower than one indicates that the shape of the lactation curve is not genetically the same for all the indi- 
Vol. 5 (1996): 185-192.

viduals. Furthermore, estimating breeding values and ranking animals on the basis of test-day records for the first two test days may not always lead to selection of the same animals that would have been selected if the decisions had been based on the later test day records.

On the basis of these results, it would be reasonable to take individual deviations from the general lactation curve into account either by estimating regression coefficients describing the lactation curve within cows, as in an approach chosen in Canada (Jamrozik et al. 1995), or by considering individual test-day observations as different traits. Fitting random regression coefficients to describe the individual lactation curves would enable lactation persistency to be included as a new trait in animal evaluation. The animal's breeding value for test-day milk pro- duction would be determined by two components: one determining the genetic mean production throughout lactation and another describing the genetic value of the shape of the lactation curve. Problems in defining the contemporary comparison groups in test-day models, the possibility of reducing the number of regression parameters in the lactation curve submodel and establishing the genetic background of the shape of the lactation curve in the Finnish dairy cow population are subjects that need to be studied in the future.

Acknowledgements. We are grateful to the Agricultural Data Processing Centre in supplying the research data. The study is a part of a larger project on utilization of test day records funded by Finnish Animal Breeding Association, Agricultural Data Processing Centre, Valio Co., Association of Rural Advisory Centres and Ministry of Agriculture and Forestry.

\section{References}

Ali, T. E. \& Schaeffer, L. R. 1987. Accounting for covariances among test day milk yields in dairy cows. Canadian Journal of Animal Science 67: 637-644.

Danell, B. 1982. Studies on lactation yield and individual test-day yields of Swedish dairy cows. III. Persistency of milk yield and its correlation with lactation yield. Acta Agriculturae Scandinavica 32: 93-101.

Gravert, H. O. \& Baptist, R. 1976. Breeding for persistency of milk yield. Livestock Production Science 3: 27-31.

Jamrozik, J., Schaeffer, L. R. \& Dekkers, J. C. M. 1995. Genetic evaluation of dairy cattle using test day yields and random regression model. Journal of Dairy Science 78, Supplement 1: 249.

Johnson, D. L. \& Thompson, R. 1995. Restricted maximum likelihood estimation of variance components for univariate animal models using sparse matrix techniques and average information. Journal of Dairy Science 78 : 449-456.

Kahtenbrink, S. \& Swalve H. H. 1993. Untersuchungen zur Erblichkeit von Leistungsvariablen der ersten Laktation von Milchkūhen. Züchtungskunde 65: 254-266.

Leukkunen, A. 1985. Genetic parameters for the persistency of milk yield in the Finnish Ayrshire cattle. Zeitschrift für Tierzüchtung und Züchtungsbiologie 102: 117-124.

Meyer, K., Graser, H.-U. \& Hammond, K. 1989. Estimates of genetic parameters for first lactation test day production of Australian Black and White cows. Livestock Production Science 21: 177-199.

Pander, B. L., Hill, W. G. \& Thompson R. 1992. Genetic parameters of test day records of British HolsteinFriesian heifers. Animal Production 55: 11-21.
Ptak, E. \& Schaeffer, L. R. 1993. Use of test day yields for genetic evaluation of dairy sires and cows. Livestock Production Science 34: 23-34.

Reents, R., Dekkers, J. C. M. \& Schaeffer, L. R. 1994. Genetic parameters of test day somatic cell counts and production traits. Proceedings of the $5^{\text {th }}$ World Congress on Genetics Applied to Livestock Production. Guelph, Ontario, Canada, Vol. 17: 120-123.

Rekaya, R., Béjar, F., Carabaño M. J. \& Alenda, R. 1995. Genetic parameters for test day measurements in Spanish Holstein-Friesian. Proceedings of the Open Session of the INTERBULL Annual Meeting. Prague, Czech Republic, Bulletin no. 11. 8 p.

Schaeffer, L. R. \& Dekkers, J. C. M. 1994. Random regressions in animal models for test-day production in dairy cattle. Proceedings of the $5^{\text {th }}$ World Congress on Genetics Applied to Livestock Production. Guelph, Ontario, Canada, Vol. 18: 443-446.

Swalve, H. H. 1994. Estimation of breeding values using testday models. Proceedings of the Open Session of the INTERBULL Annual Meeting. Ottawa, Canada, Bulletin no. $10.13 \mathrm{p}$.

- 1995a. The effect of test day models on the estimation of genetic parameters and breeding values for dairy yield traits. Journal of Dairy Science 78: 929-938.

- 1995b. Test day models in the analysis of dairy production data - a review. Archiv für Tierzucht 38: 11-32. - 1995c. Genetic relationship between dairy lactation persistency and yield. Journal of Animal Breeding and Genetics 112: 303-311.

Wood, P. D. P. 1967. Algebraic model of the lactation curve in cattle. Nature 216: 164-165. 
Kettunen, A. \& Mäntysaari, E.: Genetic parameters for test-day milk

\title{
SELOSTUS
}

\section{Ayrshire-ensikoiden koelypsykohtaisen maidontuotannon perinnölliset tunnusluvut laktaation eri vaiheissa}

\author{
Anne Kettunen ja Esa A. Mäntysaari \\ Maatalouden tutkimuskeskus
}

Tutkimuksessa tarkasteltiin ayrshire-ensikoiden maidontuotannon perinnöllisiä tunnuslukuja laktaation eri vaiheissa koelypsykohtaisten mittausten perusteella. Aineisto koottiin Maatalouden Laskentakeskuksen karjantarkkailurekisteristä kolmen eri maaseutukeskuksen alueelta (Pohjois-Savo, Keski-Pohjanmaa ja Lappi). Koelypsytulokset numeroitiin kymmeneen luokkaan sen mukaan, kuinka monta päivää oli kulunut poikimisesta mittauspäivään mennessä (DIM). Numeroidut koelypsyt luokiteltiin edelleen kolmeksi ominaisuudeksi lypsykauden vaiheen mukaan siten, että kaksi ensimmäistä koelypsyä muodostivat ensimmäisen ominaisuuden (1-60 DIM), neljä seuraavaa toisen ominaisuuden (61-180 DIM) ja neljä viimeistä kolmannen ominaisuuden (181-305 DIM). Varianssikomponentit arvioitiin usean ominaisuuden toistuvuus-eläinmallilla käyttämällä REML-menetelmää (restricted maximum likelihood) ja AI-algoritmia (average information). Periytymisasteiden arviot koelypsykohtaisille maitotuotoksille laktaation eri vaiheissa $(0,11-0,17)$ olivat alhaisempia kuin kirjallisuudessa esitetyt. Erityisesti laktaation keskivaiheen maitotuotos on yleisesti arvioitu voimakkaammin periytyväksi ominaisuudeksi kuin mihin tämän tutkimuksen tulos viittaa. Ominaisuuksien väliset geneettiset korrelaatiot vaihtelivat välillä $0,64-0,91$. Periytymisasteiden ja geneettisten korrelaatioiden keskivirheet olivat pieniä $(0,02-0,08)$. Alhaiset periytymisasteiden arviot voivat olla seurausta käytetystä mallista tai aineiston rakenteesta aiheutuvasta mahdollisesta mallin tekijöiden päällekkäisyydestä. Tulosten perusteella voidaan päätellä, että maidontuotanto lypsykauden eri vaiheessa ei määräydy täydellisesti samojen geenien perusteella. On todennäköistä, että eläinten paremmuusjärjestys jonkin verran poikkeaa koko lypsykauden koelypsytulosten perusteella tehdyn arvostelun paremmuusjärjestyksestä, jos eläimet arvostellaan lypsykauden alun koelypsytulosten perusteella. Tutkimuksen tulokset tukevat oletusta, että lypsykäyrän muodossa on additiivista geneettistä vaihtelua. Eläimen poikkeama yleisestä lypsykäyrästä on syytä mallintaa esimerkiksi satunnaisten regressiokertoimien avulla, kun arvioidaan eläimen jalostusarvoa koelypsymallilla. Tällöin eläimen jalostusarvoksi tulee sen tuotostason ja lypsykäyrän muodon yhdistelmä. 